\title{
Blanka Soukupová
}

ORCID: https://orcid.org/0000-0001-6201-9493

Faculty of Humanities, Charles University

Prague, Czech Republic

\section{Space - landscape - home - homeland Przestrzeń - krajobraz - dom - ojczyzna}

\begin{abstract}
This article endeavours to analyse the subjective experience of the landscape and its embracement by two groups of people (the Czech majority and the German minority) in the Czech lands during the first half of the $20^{\text {th }}$ century. It considers the landscape to be an optically perceivable sector with its own distinct elements, structures, important places and landmarks. It simultaneously perceives it as a space with a history and symbolic value. The Czech geologist Cilek states that "we age together with the land and trees in our home landscape". How specifically do we create this home landscape and what strategies do we choose if forced to abandon it? The actual topic of the paper and the study is therefore the relationship between the landscape and home within the meaning of a place we have assimilated with, one that evokes an emotional relationship, i.e. the origin and function of the anthropological dimensions of the Czech landscape, the interconnection between the landscape and a specific group, and the spatial map that originated as a result of new political-social conditions, and new territorial borders and even state borders.
\end{abstract}

Key words: space, landscape, home

W artykule podjęto próbę analizy subiektywnego przeżywania krajobrazu i jego zawłaszczania przez dwie społeczności (czeską większość i niemiecką mniejszość) na ziemiach czeskich w pierwszej połowie $\mathrm{XX}$ wieku. Krajobraz jest rozumiany jako strefa odbierana wizualnie, $\mathrm{z}$ własnymi wyraźnymi cechami, strukturą, ważnymi miejscami i punktami orientacyjnymi. Jednocześnie postrzega się go jako przestrzeń o wartościach historycznych i symbolicznych. Czeski geolog Cilek stwierdza, że „starzejemy się wraz z ziemią i drzewami w naszym ojczystym krajobrazie”. Jak konkretnie tworzymy ten ojczysty krajobraz i jakie strategie wybieramy, gdy zmuszeni jesteśmy go porzucić? Zatem przewodnim tematem rozważań jest relacja między krajobrazem a domem/ojczyzną w rozumieniu miejsca, z którym jesteśmy zrośnięci, które wywołuje emocjonalną więź. Analiza dotyczy antropologicznych wymiarów czeskiego krajobrazu - genezy i funkcjonowania, powiązań z określoną grupą oraz przestrzennej mapy powstałej w wyniku nowych warunków polityczno-społecznych, nowych granic terytorialnych, a nawet granic państwowych. 
Słowa kluczowe: przestrzeń, krajobraz, dom

Odebrano / Received: 31.01.2019

Zaakceptowano / Accepted: 27.08.2019

\section{The phenomenon of the landscape and its definitions*}

The phenomenon of the landscape became a research topic as early as the eighteen nineties and a number of definitions have appeared over time. Influential British historian of the latter part of the nineteenth century, Frederic William Maitland, saw a «magical palimpsest ${ }^{1}$ in the landscape. Today, the landscape is defined as an optically perceivable section of space with certain elements, objects, populations, places of spiritual importance and cultural landmarks (Kupka) ${ }^{2}$, or a «broader or narrower optically perceivable elevation of the earth's surface» (Krikavová), a territory defined by its regions (which is how the group around botanist Sádlo defined the landscape), «a specific section of dry land, with some sort of centre, a specific boundary or edge» (geologist Cílek) or as a dynamic phenomenon that originated as a result of various natural and cultural conditions (Kupka) ${ }^{3}$. In Central Europe, the landscape underwent its most revolutionary transformations from the middle of the nineteenth century, in relation to the construction of railways, extraction of raw materials and urbanisation ${ }^{4}$.

However, in the western tradition, the landscape can be understood as not only a territory or defined area, but also as a natural setting or painting and image of the landscape in $\operatorname{art}^{5}$. The trend of not examining just the natural landscape, but to include the urban landscape (as well as peripheries, factories, motorways and even waste dumps), was emphasised in modern anthropolog $y^{6}$.

\section{The landscape as a subject of research in social sciences}

However, the perception of the landscape in various periods of history, the question of its value (historic, mythical, poetic, narrative), its spirituality and the historicity of the landscape, its emotional charge and subjective experience, became the chief focus of interest of social sciences. We can also find publications that explain the temperament of the people based on the nature of the landscape in which they live. Czech sociology

\footnotetext{
The text was executed in the framework of the PROGRES Q 22 programme.

1 Kupka 2010, p. 8.

2 Kupka 2010, p. 52, p. 53.

3 Krrikavová 1997, p. 37 (Alena Křikavová was a member of the Man and Landscape in History working group at the Oriental Institute of the Academy of Sciences of the Czech Republic.). Sádlo, Pokorný, Hájek, Dreslerová, Cílek 2008, p. 11; Cílek, Ložek et al. 2011, p. 13; Kupka 2010, p. 5. Jiří Kupka from the Czech Technical University also pointed out the term a cultural landscape (Kupka 2010,p. 8).

4 Matoušek 2010, p. 316-317.

5 Lapka 2008, p. 9.

6 Compare, in this regard Kupka 2010, p. 9; Samojský 2011, p. 11.
} 
is familiar with the works of Emanuel Chalupný Národní povaha česká (The Czech National Temperament) (1907) or Jihočechové (South Bohemians) (1943) ${ }^{7}$. Willy Lorenz, an Austrian solicitor, historian and journalist with Czech roots recently attempted to describe the alleged temperament of "Sudeten" Germans in his essays, including for example, their reputed lack of a sense of humour. In his opinion, the temperament of Germans living in the Czech lands was a reflection of their life in dark, deep forests, in inhospitable regions with an inhospitable climate (winter from September until the end of April, with rainy Šumava summers) ${ }^{8}$. In his famous book Landscape and Memory (New York 1995), about the imagination of a natural environment in the western tradition, Simon Schama, a British historian, art historian and professor at the University of Columbia, a highly respected scientist and documentary maker, demonstrated that the landscape is a chiefly cultural phenomenon, a space of the imagination'. His book drew attention to the intangible (spiritual) value of the landscape, its memory ${ }^{10}$, genius loci ${ }^{11}$, and its identity. And, as demonstrated by Christian Norberg-Schulz, an architect and phenomenologist, it is the identity of a place that enables a person or group of people to identify with a place ${ }^{12}$. This is how a feeling of home or homeland originates, as pointed out by German philosopher Martin Heidegger ${ }^{13}$. German researcher Hermann Bausinger was a pioneer in the study of the link between the phenomenon of the landscape and the phenomenon of home in Central European ethnology. Jaroslava Pešková, a Czech philosopher, linked her definition of the landscape with the emotional relationship a person has to a specific place: «The landscape is... a phenomenon, which bas the nature of a horizon, closer than «world» and the related horizon of home»" She saw the landscape as a visualisation of home ${ }^{15}$.

However, man's relationship to the landscape has undergone complicated development. According to Czech historian Eduard Maur, medieval and renaissance

${ }^{7}$ Chalupný 1907 and 1943.

${ }^{8}$ Lorenz 2002, p. 50. Also compare Cílek 2008, p. 41.

${ }^{9}$ Schama 1995, p. 61; Schama 2007, p. 65.

${ }^{10}$ Geologist Václav Cílek recognised two landscape memories: natural (the ability to regenerate) and cultural (the ability to evoke an ancient history, stories, emotions...) $c f$. Cílek 2008, p. 82. The natural memory is determined by the substrate, topography, climate, while the cultural memory is determined by farming, consecration and desecration of the landscape (Cílek 2005, p. 224, p. 43). In his following book Makom, Kniha mist (Makom, The Book of Places) Václav Cílek demonstrated with specific examples that places "are....threads leading to stories, secrets and banalities"(Cílek 2009, p. 8). According to archaeologist and historian Martin Gojda, the landscape even has its own cybernetics (Gojda 2000, s. 61).

${ }^{11}$ Cílek identified the genius loci as «one of the strongest essences of the entire landscape» (Cílek 2009, p. 10). However, as Radan Květ wrote, while the spirit of the landscape was originally linked to the sacral, this concerns an aesthetic perception at most today (Květ 2003, p. 28).

${ }^{12}$ Norberg-Schulz 2010, p. 21.

${ }^{13}$ Scholz 2012, p. 21.

${ }^{14}$ Pešková 1998, p. 35-36.

15 Pešková 1998, p. 36. 
man became attached to the cultivated and safe lowlands. An aesthetic experience of the landscape only originated in the Czech lands in the seventeenth and eighteenth centuries, when - following the eradication of impassable and dangerous medieval forests - the landscape was no longer a natural threat ${ }^{16}$ and security risk. During the Romantic era, people were fascinated by the mountain landscape (particularly the alpine landscape in Europe, and the region of Šmava on a Czech scale), to which urban society began to travel ${ }^{17}$. According to Czech sociologist Hana Librová, romanticism afforded the landscape the ability to evoke emotions and the ability for people be comforted by the landscape. The preoccupation with the mountain landscape was a reaction to the fashionability of Far Eastern culture ${ }^{18}$. And it was no coincidence that landscape painting, a branch of fine art in which the landscape was promoted as the key element, originated in the nineteenth century ${ }^{19}$.

\section{Modern man and his landscapes}

Throughout his life, modern and post-modern man passes through and lives in various landscapes; however, the most powerful experience usually comes from the oldest image, the landscape of one's childhood. It seems that the summer sun never shone as brightly, the trees never flowered as much and there was never as much snow as when we were children. In his memoirs Krajina vzpominek (The Landscape of Memory), Václav Vokolek, a Czech artist from the North Bohemian town of Děčín, reflects on the gradual expansion of the childhood space (which, for him, was the run-down garden surrounding the villa of his birth, a magnificent Art Nouveau building, which had fallen into disrepair after the war) with the «garden of the landscape». In his concept, this is the town of one's birth and its surroundings ${ }^{20}$. It is only later that man is capable of stepping outside this boundary and considering his homeland as his home. However, Czech geologist Václav Cílek believes that an intimate relationship with the landscape is only born in the second or even third generation, when man is firmly anchored to this landscape through his ancestors. In his opinion, each individual can "adopt" a maximum of two or three landscapes over his lifetime ${ }^{21}$. According to Cílek, this is because: «in the landscapes of home, we age together with the soil and trees", "the landscape of home is the passage of time» ${ }^{22}$. We can admire other landscapes, but they will never be home. In modern thinking, however, the landscape, its formation, experience and understanding are usually linked not only to the idea of home, whose space has expanded since the early

\footnotetext{
${ }_{16}$ Křikavová 1997, p. 29.

${ }^{17}$ Maur 2006, p. 10-11; 12-13.

${ }^{18}$ Maur 2006, p. 13; p. 14-15.

${ }^{19}$ Clark 1949, p. 131.

${ }^{20}$ Vokolek 2000, s. 31.

${ }^{21}$ Cílek 2008, s. 39, s. 72.

${ }^{22}$ Cílek 2008, s. 72.
} 
modern era, but also to the highly abstract concept of homeland ${ }^{23}$. As Lech M. Nijakowski, a Polish sociologist states, it was the development of national movements (nationalism in his terminology) that increasingly strongly linked space with abstract terms such as nation, national state and homeland ${ }^{24}$. During the establishment of the modern nation, ${ }^{25}$ the geographic space, and its natural and plant motifs, achieve national-political significance ${ }^{26}$. The linden tree or linden leaf became the Czech plant symbol, with the oak and cornflower the symbols of the Germans, the most populous minority living in the Czech lands ${ }^{27}$ since the thirteenth century ${ }^{28}$. While the linden tree symbolised Slavic softness, subtlety and peacefulness, the robust oak was meant to express the German hardness and robustness ${ }^{29}$. The hilly Czech landscape, with its perfect harmony of waters, meadows and forests, was characterised by soft lines, a picturesqueness, geniality and intimate dimension. The simple Czech rural cottage, from which all Czech patriots allegedly came, became another Czech national-political symbol in the nineteenth century $^{30}$. The poor, but neat cottage, with a thatched or shingle roof, continued to become part of the Czech consciousness over the following decades. It became the attribute of all prominent Czechs, including the first Czechoslovak president T. G. Masaryk. The alleged plebeian or democratic nature of the $\mathrm{Czech}$ nation was actually derived from this symbol of the landscape. According to Clifford Geertz, an

${ }^{23}$ Home was originally linked to property, the ownership of a house. In the $19^{\text {th }}$ century, the century of a performance-based and uncertain society, home became a place of compensation, self-realisation and idealisation. A political dimension was subsequently added; home became equated with homeland (Bausinger 1990, p. 77-80).

${ }^{24}$ Nijakowski 2006, p. 59.

${ }^{25}$ However, according to archaeologist Václav Matoušek, the term «our landscape» appeared for the first time in a Czech context when used by Josef Jungmann, the creator of standard Czech, or ethnographic writer František Sušil, in the first half of the $19^{\text {th }}$ century (Matoušek 2010, p. 180).

${ }^{26}$ With regard to the symbolism of the types of landscape in modern nations, in summary Hroch 2009, p. 259-265; Maur 2006, 11.

${ }^{27}$ In 1880, Czech Germans living in post-war Czechoslovakia made up 35.78\% of the population $(2,927,362)$, in 1890 this number rose to $35.63 \%(3,087,204)$, and again in 1900 to $35.10 \%(3,289,616)$, but fell in 1910 to $34.65 \%$ (3,492,362), cf. Srb 1988, p. 30. Regarding the German population during the First Republic, compare Machačová, Matějček 1999, p. 110-111. In 1921, there were 3,061,000 Germans living in Czechoslovakia (30.60 \% of the population), in 1930 this was 3,150,000 (29.58 \% of the population), Machačová, Matějček 1999, p. 111. Prague, the metropolis of the Czech lands, had a majority Czech population. During the eighteen sixties, Germans made up just under twelve percent of the Prague population. In 1890, Prague had a German minority of roughly 10\% (this percentage includes Jews who identified with the German community through language), in 1910 this percentage fell to 6\%. Downloaded statistical data, compare Soukupová 2008, p. 24 (ibidem references to additional specialist literature). According to American historian Gary B. Cohen, we can call Prague Czech in the last third of the nineteenth century (Cohen 2000, p. 112-113).

${ }^{28}$ On the arrival of German in the Czech lands, in summary Seibt 1996, p. 66-72.

${ }^{29}$ Jaworski 2004, p. 3-4.

${ }^{30}$ Hroch 1999, 256. 
American anthropologist, meanings are hidden in symbols. However, each culture has a limited number of symbols. People or groups of people can organize their lives according to them ${ }^{31}$. Another influential Czech myth was that of the Czech farmer as the core ${ }^{32}$ or heart of the nation, the farmer as the natural defender of the nation, its language and soil. However, this romantic $\mathrm{Czech}$ perception of the farmer was influenced by the romantic perception of the peasantry in the mid $-19^{\text {th }}$ century in Germany ${ }^{33}$.

The artistic portrayal of the landscape and its dominant features, which remained nationally neutral at the beginning of the $19^{\text {th }}$ century, could have had dual importance in the formation of national-political identities: 1. to evoke and reinforce affection for the landscape and the ability to empathise with the landscape (e.g. the paintings of W. F. Jäger /1861 - 1928/ who painted the Jizera Mountains could have had this effect), 2. to attribute specific meanings to the landscape, including national or nationally mobilising meanings. Art could have become a means to promote tolerance, however, it could also promote aggressive political nationalism. We can also say that German art and literature in the Czech lands was marked by strong regionalism ${ }^{34}$. In his book Pamét hor (The Memory of the Mountains), Czech historian Eduard Maur described the conflict between the two national concepts of the literary image of Šmava: the German view by Josef Ranke (in the book Aus der Böhmerwalde, 1843), emphasised the link between the German residents of Šumava and Bavaria, not their Czech neighbours, while the Czech view by Czech writer Božena Němcová (in her ethnographic Obrazy z okoli domažlického /Pictures from the the Domaźlice Region/, 1845-1846), expressed admiration for local Czech vernacular culture ${ }^{35}$. At the same time, the image of the heroic Šmava Mountains, which stopped an attack by the German enemy (by revivalist dramatist Jan Nepomuk Štěpánek, poet Jan Erazim Vocel and particularly writer Eliška Krásnohorská (Ze Šumavy /From Šumaval, 1873) appeared in Czech literature ${ }^{36}$. Both directions of art: the development of tolerance and nationalism were recently demonstrated - again using the example of literature from Šumava - by Martin C. Putna, a Christian literary critic and Prague university professor. According to Putna, Adalbert Stifter (1805-1868), a native of Šmava, portrayed the nationally neutral region of the Upper Vltava, initially as a traveller and later a "mature" Stifter, as a native. However, the "later" Stifter passed on his idea of Šumava as a common Czech-German space to Czechs and

\footnotetext{
${ }^{31}$ Geertz 2000, p. 148, 245.

${ }^{32}$ Hroch 2010 (this concerns a comparison of the beginnings of Central European agrarian movements.)

${ }^{33}$ Lenz 1912, p. 73-78. Subsequently very successfully incorporated by Walter Darré into the Nazi ideology (Mommsen 2001). "Deutschland ist in den Anfängen seiner Entwicklung ein Agrarstaat, ein Bauerland gewesen,» wrote Darré in the introduction of his book Der Bauernspiegel (1940).

${ }^{34}$ For example, we can find a portrayal of the Cheb region in the works of Nikolaus Krauss, the Jizera region in the books of Gustav Leutelt, Sumava in the texts of Adalbert Stifter, R. Michle and Hans Watzlik.

${ }^{35}$ Maur 2006, p. 37-41.

${ }^{36}$ Maur 2006, p. 43-48.
} 


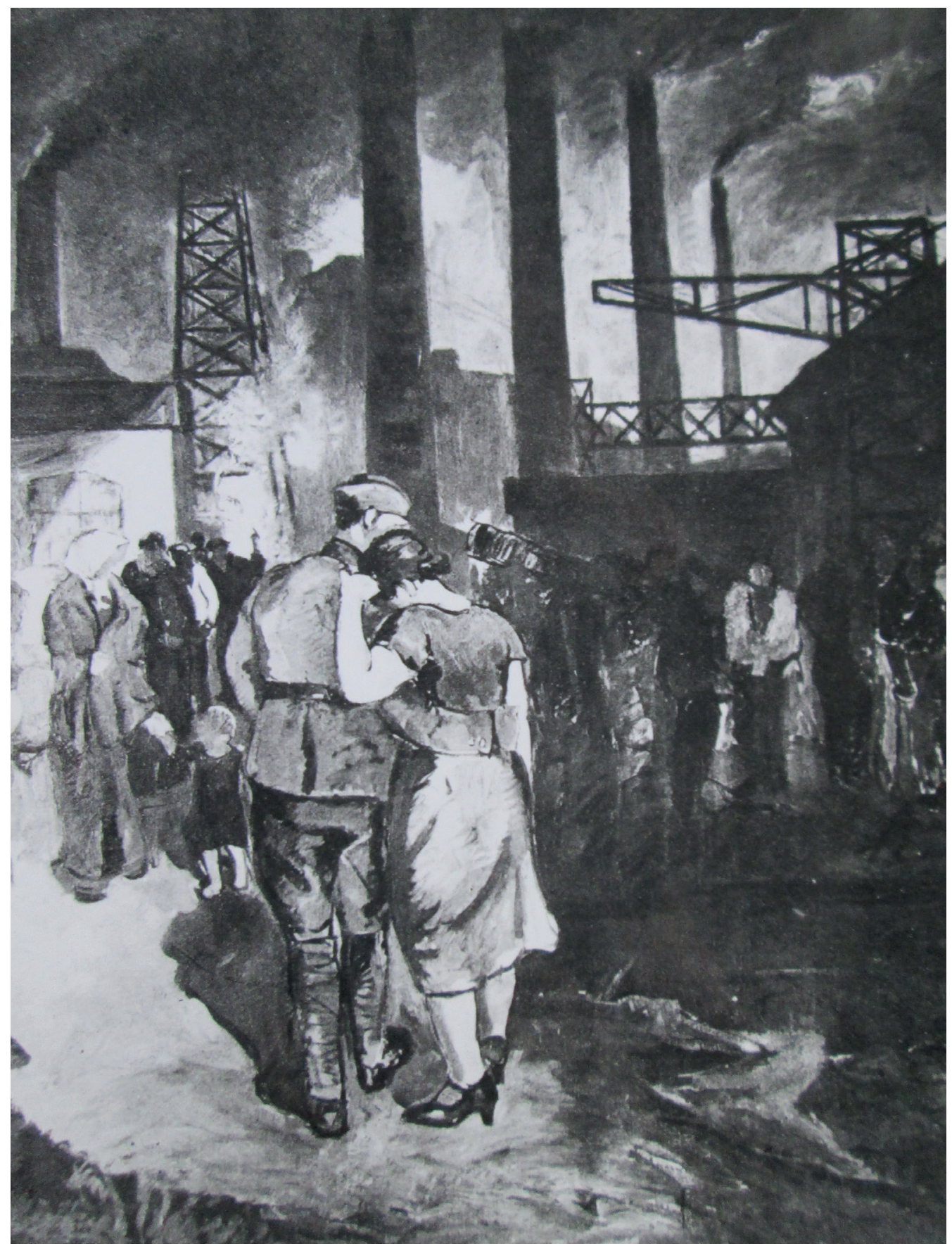

Z továrny (From the factory), photographer B. S.Urban, "Zlatá Praha", Vol. 46: 1928-1929, No. 13, p. 251 


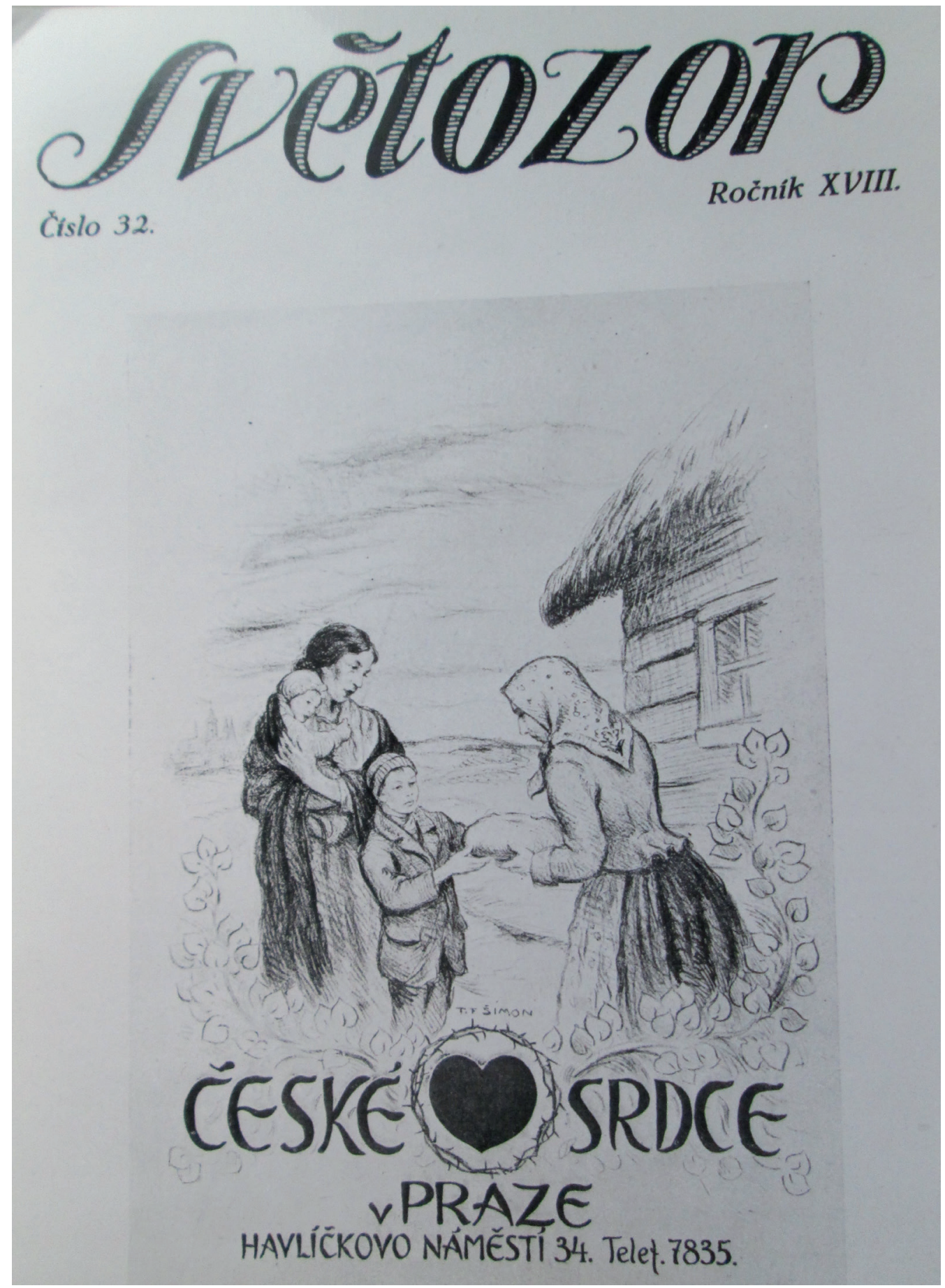

České srdce v Praze (Czech heart in Prague), "Světozor", Vol. XVIII: 1918, No. 32 


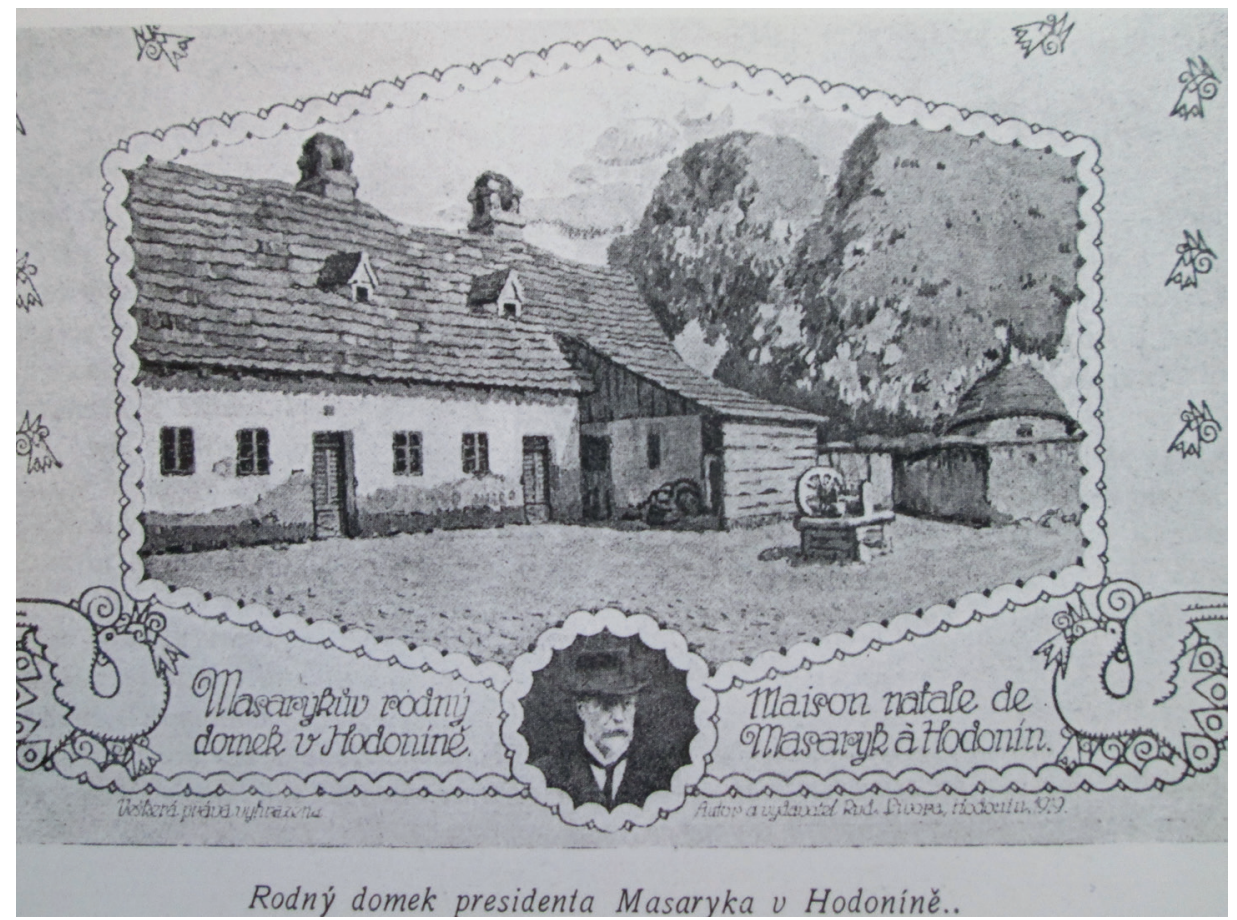

President Masaryk's family home in Hodonín, "Světozor" Vol. XX:1920, No. 7

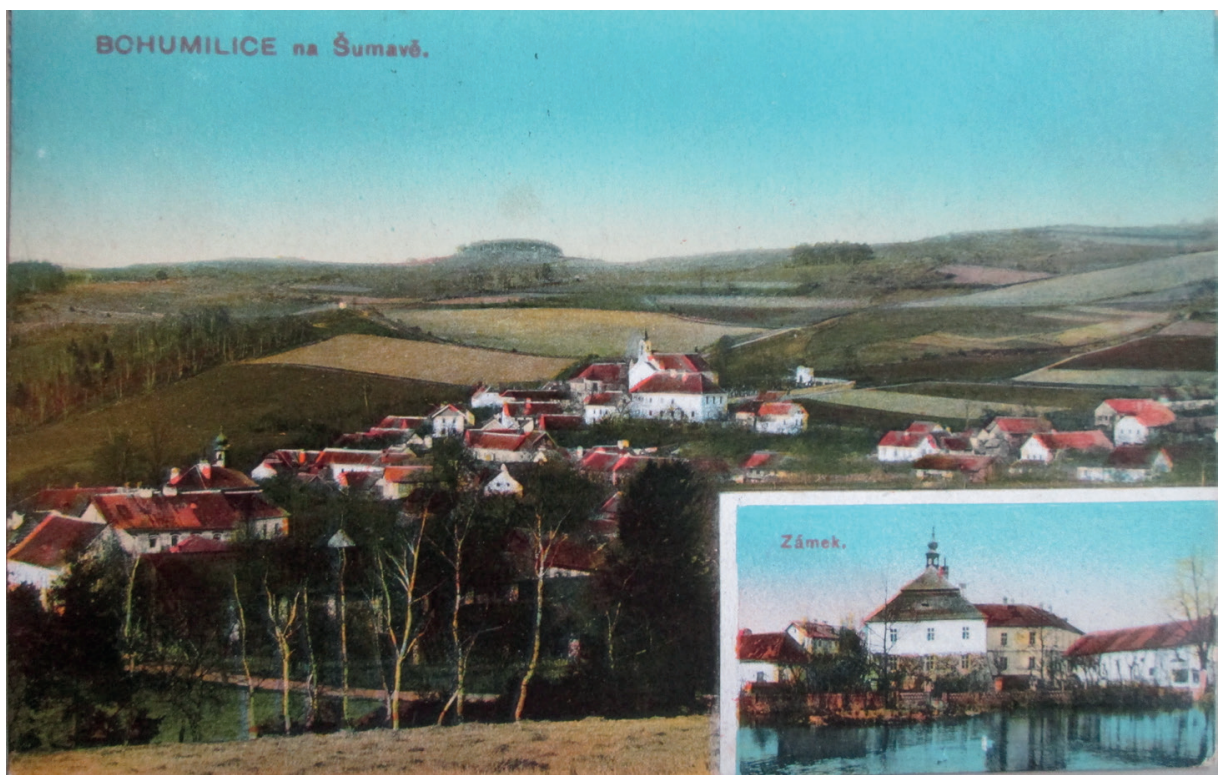

Bohumilice na Šumavě (the landscape of Šumava on period photographs), private archive of B. Soukupová 
Germans $^{37}$. Nevertheless, the Nazi ideology, tied to the romantic German obsession with the forest ${ }^{38}$, interpreted Stifter's novels as works attacking liberalism and modernity ${ }^{39}$. In an irony of history, Stifter actually became a symbol of Sudeten Germanism after the Second World War ${ }^{40}$. Prague writer Johannes Urzidil (1896-1970) followed in Stifter's footsteps ${ }^{41}$. Karel Klostermann (1848-1923), portraying Šmava in the Otava River basin (as a goddess in fact), also remained religiously and nationally tolerant in spite of his transition from German to Czech literature. Not even Klosterman's positive portrayal of the Czech population of Šmava in counterpoint to the German population of Sumava in his early works could change this fact ${ }^{42}$. «I love my entire homeland, this entire Czech land, not just a small part of it... not two territories, that the national demarcation fanatics would like to demarcate and enclose with some fantastic Chinese Wall,» the writer professed in his memoirs ${ }^{43}$. However, a predominantly national neutrality was not intrinsic to just Karl Klostermann, but also to Andreas Hartauer (1839-1915) for example. He was a glassmaker from Šumava and the author of the famous song Böhmerwaldlied (originally Tief drin im Böhmerwald), which also existed in a Czech version. This sentimental song originated in memory of his native land, his homeland (Heimatland) while Hartauer was working in north Bohemia. It only acquired national connotations much later in the Czech-German environment: the former Germans of Sumava adopted it as their national anthem in their new home after they were displaced ${ }^{44}$.

In contrast, the Šumava stage of Hans Watzlik (1879-1948) around the Úhlava River with its forests and mountains, was evidently meant to support the Sumava-German cultural revival. Watzlik, who actively collaborated with the Nazis, considered the Czech lands as a specific German cultural space. However, in 1939 Watzlik moved on to the theory that Sumava was a natural part of Bavaria ${ }^{45}$. And it was also Watzlik who declared the famous poem Wiculturaltiko to be ideologically identical to the expansive tendencies of the Third Reich in January $1939^{46}$.

The Czech and German adoption and marking of the landscape was supported not only by art, but also by hiking/tourism ${ }^{47}$. From the perspective of the German national press, organised Czech trips into areas of the Czech lands with a majority German

${ }_{37}$ Putna 2001, p. 57-64.

${ }^{38}$ This obsession was an expression of their aversion to Roman urban civilisation (Schama 1995, p. 69-74).

39 Schama 2007, p. 127

${ }^{40}$ Hahnová, Hahn 2002, p. 96-98.

${ }^{41}$ Putna 2001, p. 64-68.

42 Putna 2001, p. 72-79.

${ }^{43}$ Klostermann 2006, p. 17.

${ }^{44}$ Maur 2006, p. 52-53.

${ }^{45}$ Putna 2001, p. 82-95.

${ }^{46}$ Watzlik 1940, p. 67.

${ }^{47}$ With regard to the development of hiking activities, in summary Matoušek 2010, p. 185-191. The first hiking association in the Czech-German environment originated in Karlovy Vary (1861), the first such 
population, particularly from the end of the eighteen eighties, were actually perceived as a threat to the German landscape ${ }^{48}$ and home.

\section{Space, homeland, state, home}

However, when the space with which the homeland was identified, deviated in people's thoughts from a form of the state, the feeling of home also disappeared. Social scientists repeatedly demonstrated that in modern times the mental spatial maps of the members of national ethnic or religious groups living in a specific area, did not have to be identical to territorial or state borders. «Geography is the fate of the nation,» said Franz Spina, a Czech-German activist politician in 1932 in Prague ${ }^{49}$. In specific socio-political situations there can be an escalation in relations between nationalism or another ideology and territoriality, which harbours the threat of an individual or even group loss of a destined space, landscape or home.

The Czechs experienced a territorial crisis after the Munich Agreement in September 1938, when the borders areas of the Czech lands were forcefully annexed. The Czech democratic public pondered on the mutilation of the national body (immediately after Munich, Czech thoughts even turned to the consoling idea of the transformation of the annexed landscape - mountain zones, sources of Czech rivers, into the hearts of members of the Czech nation) ${ }^{50}$. In contrast, German nationalists and Czech collaborators during the so-called Second Republic and subsequently during the protectorate ${ }^{51}$, celebrated the "return" of the annexed border area of the Czech lands to ancient German territory. On-going efforts by the Nazis to aggressively take control of the entire area of the Czech lands, endangering the actual existence of the Czech nation, gave rise to the consoling nostalgic image of a picturesque $\mathrm{Czech}$ landscape ${ }^{52}$, which was intended to symbolise the persistence of the Czech nation throughout history and the geographic space of the Czech lands, in the ethnic Czech counter-pole.

A textbook example of the disrupted triad of the home as a place of safety and happiness - the homeland and state as a power-based and political formation, was also the displacement of Czech Germans from Czechoslovakia after the Second World War,

association in the Czech environment originated in Frenštát pod Radhoštěm (1884). The Czech Hiking Club in Prague was established in 1888 (Maur states 1884). Maur 2006, p. 16.

48 On the example of Šumava, Maur 2006, p. 55-56.

${ }^{49}$ Regarding the statement printed in, for example, the Czechoslovak Republic daily (7 June 1932), and its Czech parallels, compare Soukupová 1994-1996, p. 66 and p. 80.

50 The conclusions are based on excerpts from the Czech press during the period of the so-called Second Republic.

51 They criticised the former European space as an «impassable undergrowth of various border areas» (Minister Emanuel Moravec 16 June 1942 in Plzeň) and glorified the opportunity of the Czech "people" to be part of the territory of the Great German Empire (e.g. Moravec 23 June 1942 in Hradec Králové). V hodině dvanácté (At the twelfth hour) 1942, p. 49, p. 66.

52 Soukupová 2007a, p. 22. 
which ended centuries of $\mathrm{Czech}-\mathrm{German}$ cohabitation. The minority of $\mathrm{Czech}$ Germans, who were not included in the so-called displacement, identified their homeland (Heimat) with the Czech lands. However, some of the displaced forever linked their home (homeland) to a specific location in the Czech lands and a specific landscape. This usually concerned the landscape of their childhood, which people idealised in their memories. In the case of displaced Germans, however, we also encounter the term "new homeland" 53 , or two terms home (Germany) and homeland (the Czech lands) ${ }^{54}$.

However, the fact that there was no single standardised Czech-German landscape, but a group of diverse landscapes (according to natural scientists, the Czech landscape is characterised by its high degree of diversity in genera ${ }^{55}$ ), was important in the formation of a Czech-German identity in the Czech lands. This fact also meants that various experiences with the landscape were recorded in the memory of Czech-German generations. Germans settled the sparsely populated Šumava region with its sweeping mountain ridges, dense coniferous forests and beautiful lakes, where contact with granite and wood formed a distinctive culture according to $\mathrm{C}^{1}$ lek ${ }^{56}$, and which was also the location of the source of the Vltava River, a Czech river with an important place in national mythology, passing Czech castles and linking the border areas to Prague, and whose landscape was the symbol of Czechness ${ }^{57}$.

They also settled the Cheb Region with the city of Cheb dating from 1061 - the gateway to the Czech lands, the chalk region of the Ore Mountains with its lower mountain ranges, the $\check{Z}$ atec region, the hop-growing region in the foothills of the Doupov Mountains, the volcanic Central Bohemian Highlands, the fertile region of the Elbe river basin, the Ploučnice-Nisa lowlands (including the wet, forested, volcanic Lusatian Mountains), the sharply defined Giant Mountains with storeys of coniferous forests transitioning to mountain pine and meadows, the mountain range with the oldest summer resorts, the Jizera Mountains with sweeping wide parallel ridges covered in coniferous forest, with quiet valleys and numerous dams, the Orlice Mountains, a separate geomorphologic entity in the Giant-Jesenice area, the forested Jeseník Mountains (Hrubý Jeseník with its wide ridges and deep valleys and Nízký Jeseník which is essentially a plain), the Kravař region in the north-east of Moravia, South Moravia, the largest language island of the Hřebeč region with its centre in Moravská Třebová. They also created the Olomouc, Vyškov, Brno and Jihlava language islands. These landscapes also had diverse climates (heavy rainfall is particularly recorded

\footnotetext{
${ }^{53}$ Soukupová 2008 , s. 79 , p. 80.

${ }_{54}$ Hahn 1998, s. 111, p. 131-133.

${ }_{55}$ Matoušek 2010, p. 26.

${ }^{56}$ Cílek 2008, p. 75.

${ }^{57}$ Regarding the symbolic importance of rivers, compare Soukupová 2007b, p. 26, p. 30, p. 31-33.
} 
in the Jizera Mountains and the Giant Mountains, a damp climate and fog are also typical for Šumava, while the Ore Mountain area is dry) and different types of forest ${ }^{58}$.

\section{The post-war border areas of the Czech lands - an example of a misappropriated and foreign landscape}

The expulsion and displacement of the Czech Germans, the cruel aftermath of a cruel war, understandably retroactively affected the characteristics of the border areas, which the Czech Germans had populated. In the period after the Second World War, the area was characterised by extensive destruction, which had no parallel in the Czech interior. The violent intervention in the landscape was probably best recorded in various memoirs. But there are also expert, scientific and popularising reflections alongside these memoirs in a number of diversely interest-based texts ${ }^{59}$. The ignorant and insensitive relationship between the new residents and the landscape was, criticised in the Czech press as early as $1946^{60}$, albeit infrequently. The people who came to the border areas (spontaneously and in a controlled manner) after the Second World War, the so-called new settlers, found themselves, figuratively speaking, in a foreign land. They strove to eliminate everything they considered to be an expression of Germanism from the

\footnotetext{
${ }^{58}$ Matoušek 2010, p. 29.

59 The book (and preceding photographic exhibition) Verfall einer Kulturlandschaft am Beispiel des Alt-Landkreises Mies im Egerland, for example, had a clear political tendency. Mirtes 1992. However, the devastated border landscape was also documented in a number of books of Czech provenience. Emotionally charged impressions of the devastated border areas of the Czech and Moravian landscape were published during the so-called normalisation period (1987) in Munich, obviously with sharp criticism of the national policy of the Frist Republic (Ztracené dějiny /Lost History/ by Petr Příhoda / František Jedermann/). The previously cited memoirs by Václav Vokolek were published after 1989. These describe post-war Děčín in the «depopulated Sudeten lands», in «essentially a foreign land», in «spiritual peripheries», which the new residents transformed into a "city with no face», «without a history» (p. 9, p. 23). Vokolek particularly remembers the rash destruction of antique furniture and porcelain by the new residents of the border areas, with no connection to local history (p. 23), the post-war destruction of furnishings, churches and cemeteries (p. 32). The liquidation and elimination of everything German was then rightfully described as a method by which the new settlers adopted the unknown space (p. 32). However, he dates the actual destruction of the character of Děčín in the nineteen seventies (p. 32). Works by young researches set in the devastated landscape of the border areas that endeavour to renew Czech-German dialogue throughout the border areas with the reputed potential of "multiculturalism", have also appeared in the last decade. For instance, culturologist Petr Mikšiček actually stylised himself in the role of post-modern traveller through a schizophrenic landscape, sacrificed mountains, a sterilised landscape. In his travels, he described the border areas, for which he strictly uses the political term Sudeten Lands, as the space of an extinct civilisation, the damaged Sudeten spirit (Mikšíček 2005, p. 24, p. 86, p. 144). The book Zmizelé Sudety (The Disappeared Sudeten Lands), which was published repeatedly in the last decade (2003, 2004, 2006, 2007, 2015), shows a similar tendency; cf. Mikšíček, Spurný, Matějka, Spurná $(2003,2004,2006,2007,2015)$.

${ }^{60}$ Soukupová 2009, p. 57.
} 
landscape. This is why they began, in spite of the shortage of building materials, to modify the masonry, stone and half-timbered German border houses (for example, they plastered over half-timbers - a trait of German houses) ${ }^{61}$, and whitewashed dark rooms, typical for German households ${ }^{62}$. It was only later that the enormous intervention in the border area landscape became clear in the destruction of the housing fund, sacral and funeral architecture and in the devastation of nature. Hundreds of extinct villages and settlements ${ }^{63}$ that were occupied and closed by the Czechoslovak Armed Forces in the area, were only marked by nettles. Wire fences under high-voltage were built on the borders with West Germany and Austria. Household manufacture, which formerly codetermined the use of the landscape, also died in border areas after the Second World War ${ }^{64}$. Miroslav Lapka of the Society for Sustainable Development pointed out that the border area of the Czech lands had achieved the character of the current Czech interior as early as the nineteen fifties, which is characterised by the abandonment of agricultural land, depopulation of rural areas and extinction of small-scale infrastructure ${ }^{65}$.

After their forced departure from the Czech lands, the Czech Germans gave new meaning (intentionally and inadvertently) to the space and landscape of the Czech lands through reflection. The most radical group of Sudeten Germans continues to emphasise the link between the so-called Sudeten Lands and Germany, «which have always been a natural component (including the 1938-1945 period - comment by BS) of the Sudeten Lands». In this concept, Prague is perceived as the Capital City of the Holy Roman Empire of the German nation, where it is usually emphasised that Prague has played this role for longer than Berlin ${ }^{66}$. However, on the other hand, attention is currently being devoted to people for whom life on the borders was a source of multicultural creativity and an attitude to life (to name at least one, writer and translator Josef Mühlbergera, a native of Trutnov/1903/, the author of the thesis of a single homeland, for who the impulse of the landscape was of enormous importance in his work) ${ }^{67}$.

However, in many cases the radically national-political construct of the border areas and Prague (the collective memory of Sudeten Germans) is not identical to the mentality of regular displaced Czech Germans. Numerous post-war memoirs by

${ }^{61}$ Vařeka 1985, p. 67, p. 69. However, studies indicated the fear of the tectonics of timbered buildings as the reason for the removal of German elements for political reasons.

${ }^{62}$ Kadeřábková 1985 , p. 7.

${ }^{63}$ von Arburg, Staněk 2011, p. 188-190.

${ }^{64}$ Ethnologist and historian Helena Nosková demonstrated this on the example of the Sokolov Region (Nosková 1991, p. 106-116).

${ }^{65}$ Lapka 2008, s. 13. Ivan Plicka subsequently describes the new settlers, who replaced the Germans (farmers), as consumers in the same book (Plicka 2008, p. 8).

${ }^{66}$ Jandl 2003, Fakta sudetonèmeckých dějin (Facts of Sudeten History), Foreword, p. 33.

${ }^{67}$ Lange-Greve 2003. The book Liebe zu Böhmen, Ein Land im Spiegeldeutschsprachingen Dichtung, an anthology published by Bruno Brandl, can also be rated positively. 
displaced first and second generation Germans, in which their close connection to their native landscape is repeatedly mentioned, afford various viewpoints of nationalisation in the Czech space from the nineteen thirties, the current radical organisation of the displaced in Germany and - although infrequently - the act of actual displacement itself. The forceful removal of homes, which were lost to subsequent generations of Czech Germans, remain flooded with sunlight (this being only infrequently disrupted by conflicts within the family, which were not linked to ethnicity) in descriptions until the end of the Second World War ${ }^{68}$. In contrast, the inclination of Czech German families towards the Henlein and German Reich Nazi movement in the nineteen thirties, is conversely downplayed in practically all Czech-German memoirs ${ }^{69}$. On the contrary, human empathy with the Jewish population and very good pre-war and wartime contacts with Czechs in border areas are often emphasised ${ }^{70}$. These memories of the idyllic landscape of the Czech lands, the landscape of home, as well as the maintenance of mutual contacts with natives from the Czech lands, the activities of their associations and press, national history activities, etc., were and are indisputably one of the pillars of the new post-war identity of Czech Germans - the identity of the so-called Sudeten German ethnic group - the identity of exiles ${ }^{71}$, which was also reinforced by the traumatising experience of post-war German society until the nineteen sixties. According to Hans Dieter, a literary scientist from Berlin, the displaced Czech Germans remained second-rate citizens in their new land for many years ${ }^{72}$. However, expatriate organisations and their press, seemingly paradoxically increased and continue to increase the persisting failure by the older generation to anchor themselves in German society and identify their home with the social structures brought with them from the Czech lands ${ }^{73}$, which, as was appositely pointed put by German-Czech-Jewish political scientist Eva Hahn, portray the landscape of home in the Czech lands in the long extinct sentimental, agrarian and idyllic image of the end of the nineteenth century ${ }^{74}$. As a result, the Sudeten Germans experienced a feeling of dual loss: the loss of the landscape of their home, from which they were displaced, and the loss of an idyllic environment, which they would be unable to experience today even if they had been permitted to stay in their homes.

\footnotetext{
${ }^{68}$ Further compare, for example, the memoirs of Johanna Manhart (born 1921) of the life of a labourer's family in the South Moravian border town of Losová 1996, p. 310-316.

${ }^{69}$ The uncommonly open memoirs of Hubert Sigmund, for example, are an exception Sigmund 2006.

${ }^{70}$ Compare Wagnerová 1993. The German experience of trade in the Czech landscape is also recorded (Althammer-Švorčíková, Wagnerová 2004).

${ }^{71}$ Eva Hahn places the origin of this identity in the fifties. Hahnová 1999, p. 17.

72 Zimmermann 2009, p. 214.

${ }^{73}$ Compare the results of research among forty women from the Hessen Region in 1988-1990. Hahnová 1999, p. 156-157. See also Götz 2003, p. 306.

${ }^{74}$ Hahnová 1999, p. 320-321.
} 
However, the second generation of exiles does not have such authentic experiences from home. A detailed narrative topography and markedly unchanging nature remain characteristic of the description of the landscape of their childhood by witnesses. Those who were displaced when they were children or in their youth, mainly identify the landscape of their home with the house of their birth, its garden and the immediate surroundings, in which they were accompanied by their family. Their relationship to organised Sudeten Germanism varies. The hope for the good quality of a jointly experienced European space is also based on the fact that the second generation of displaced Germans has a much more balanced relationship with the Czech nation then the generation of their parents.

\section{Conclusion}

The nostalgic song Kde domov muj (Where My Home Is) from the nineteen thirties, which became part of the national anthem of the Czech Republic a hundred years ago, glorifies the beauty of the Czech landscape, which is a visualisation of home. While in their part of the Czechoslovak and now Slovak anthem, the Slovaks celebrated, in the spirit of evangelical tradition, the massive Tatra Mountains ${ }^{75}$, the Czech landscape, with its meadows, forests, cliffs and waters, is less magnificent and more intimate, but also very diverse. Its indisputable aesthetic value undoubtedly contributed to the fact that generations of Czechs and members of ethnic minorities felt at home here and brought its image with them after their displacement or emigration abroad, where it remained a symbol of home.

The interests of countrymen and compatriots were frequently politicised and divided as a result of the origin of modern nations and states. Problems occurred when the landscape was considered home, but not the state of which it was part. The Czech lands, as the centre of an uneasy Central Europe, have experienced territorial crises repeatedly in modern times; however, the Munich Agreement (the dismantling of the First Republic) and post-war displacement of the Germans, had the greatest effect on the landscape.

\section{Bibliography}

Althammer-Švorčíková E., Wagnerová A. 2004, Češi jsou vlastně docela milí.. Česko-nèmecké vzpominky, Prostor, Praha.

Bausinger H. 1990, Heimat in einer offenen Gesellschaft, Begriffsgeschichte als Problemgeschichte, [w:] Cremer W., Klein A. (Hrsg.), Heimat, Analysen, Themen, Perspektiven, Bundeszentrale für die politische Bildung, Bonn, s. 76-90.

${ }^{75}$ Macura 1983, p. 163-164. 
Chalupný E. 1907, Národní povaha česká, nákl. vl., Praha.

Chalupný E. 1943, Jibočechové, Č. A. T., Praha.

Cílek V. 2005, Krajiny vnitřni a vnèjší: texty o pamèti krajiny, smysluplném bobrovi, areálu jablkovébo štrúdlu a také o tom, proč lezeme na rozhlednu, Dokořán, Praha.

Cílek V.2008, Dýchat s ptáky: obyčejné texty o světle paměti, pravdě oblakio a útěše mist, Dokořán, Praha. Cílek V. 2009, Makom, Kniha mist, Dokořán, Praha.

Cílek V., Ložek V. et. al., 2011, Obraz krajiny, Pohled ze střednich Čech, Dokořán, Praha.

Clark K. 1949, Landscape Into Art, J. Murray, London.

Cohen G. B. 2000, Nèmci v Praze 1861-1914, Karolinum, Praha.

Darré R. W. 1940, Der Bauernspiegel Gro3deutschlands, in: Springenschmid K., Strohmeyer K. (eds.) [1940], Der Bauernspiegel Gro3deutschlands, Philipp Reclam jun., Leipzig.

Geertz C. 2000, Interpretace kultur, Slon, Praha.

Gojda M. 2000, Archeologie krajiny: vývoj archetypi̊ kulturní krajiny, Academia, Praha.

Götz A. 2003, Domov - otčina/Heimat - Vaterland, [w:] Koschmal W., Nekula M., Rogall J., Deutsche und Tschechen: Geschichte, Kultur, Politik, C. H. Beck, München, s. 11-17.

Hahn E. 1998, Die Sudetendeutschen in der deutschen Gesellschaft: ein halbes Jabrhundert politischer Geschichte zwischen „Heimat“ und „Zuhause“, [w:] Lemberg H., Křen J., Kováč D. (ed.), Im geteilten Europa, Tschechen, Slowaken und Deutsche und ibre Staaten 1948-1989, Institut für Kultur und Geschichte der Deutschen im östlichen Europa, Essen, Klartext, s. 111-133.

Hahnová E. 1999, Sudetonèmecký problém: Obtǐnné loučeni s minulostí, Albis international, Ústí nad Labem.

Hahnová E., Hahn H. H. 2002, Sudetonèmecká vzpomináni a zapominání, Votobia, Praha. Hroch M. 1999, Na prahu národni existence. Touba a skutečnost, Mladá fronta, Praha.

Hroch M. 2009, Národy nejsou dílem náhody, Přiciny a předpoklady utvářeni moderních evropských národi̊, Sociologické nakladatelství Slon, Praha.

Hroch M. 2010, Bauern und Agrarfrage in den nationalen Berwegungen Mitteleuropas, [w:] Schultz H., Harre A. (ed.), Bauerngesellschaften auf dem Weg in die Moderne, Agrarismus in Ostmitteleuropa 1880 bis 1960, Harrassowitz, Wiesbaden, s. 87-104.

Jandl H. 2003, Fakta sudetoněmecko-českých dějin, Bund der Vertriebenen, Landesverband Hessen, Wiesbaden.

Jaworski R. 2004, Značkováni pozic. Národni mýty a symboly na poblednicích z českých zemí kolem roku 1900, „Dějiny a současnost“, Vol. 26, No. 6, s. 3-6.

Jedermann F. 1987, Ztracené dějiny, Tschechischer Nationalauschuss in Deutschland, München.

Kadeřábková J. 1985, K stavebnimu vývoji v pohraničnich vesnicich Broumovska, „Český lid“, Vol. 72, No. 1, s. 4-10.

Klostermann K. 2006, Vzpominky na Šumavu, Kniba pamétí, Hrad, Strakonice.

Křikavová A. 1997, Svèt za hradbami mèsta (Krajina v islámském svètě), [w:] Křikavová A., Obuchová L. (ed.), Krajina v dějinách člověka, Česká orientalistická společnost, Dar Ibn RUSHD, Praha 1997, s. 28-41. 
Kupka J. 2010, Krajiny kulturni a historické: vliv hodnot kulturni a historické charakteristiky na krajinný ráz naši krajiny, České vysoké učení technické v Praze, Praha.

Květ R. 2003, Duše krajiny. Staré stezky v proměnách věkü, Academia, Praha.

Lange-Greve S. 2003, Život na hranicich, Josef Müblberger 1903-1985, Publikace ke 100. výroči jeho narození, Einhorn-Verlag, Schwäbisch Gmünd.

Lapka M. 2008, Zánik zemèdělské krajiny v Sudetech, [w:] Spurný M. (ed.), Proměny sudetské krajiny jako poselstui dalším generacím, Společnost pro trvale udržitelný rozvoj, Praha, s. 94-100.

Lenz F. 1912, Agrarlehre und Agrarpolitik, P. Parey, Berlin.

Lorenz W. 2002, Dialog s českou zemi: esejistické črty a imprese, Gemini 99, 2002.

Losová J. 1996 (ed.), Kindheit in Böhmen und Mähren, Böhlau, Wien, Köln, Weimar.

Machačová J., Matějček J. 1999, Sociálni pozice národnostnich menšin v českých zemích 1918-1938, Slezský ústav Slezského zemského muzea.

Macura V. 1983, Obraz Prahy v české obrozenecké kultuře, [w:] Město v české kultuře 19. století, Národní galerie, Praha, s. 154-167.

Matoušek V. 2010, Čechy krásné, Čechy mé, Proměny krajiny Čech v době industriální, Krigl, Praha.

Maur E. 2006, Pamét’ hor: Šumava, Řip, Blanik, Hostýn, Radhošt', Havran, Praha.

Mikšíček P. 2005, Sudetská pout', aneb Waldgang, Dokořán, Praha.

Mikšíček P., Spurný M., Matějka O., Spurná S. 2003, Zmizelé Sudety, Pro o. s. Antikomplex vydalo nakl. Český les, [Domažlice].

Mikšíček P., Spurný M., Matějka O., Spurná S. 2004, Zmizelé Sudety, Pro o. s. Antikomplex vydalo nakl. Český les, [Domažlice].

Mikšíček P., Spurný M., Matějka O., Spurná S. 2006, Zmizelé Sudety, Pro občanské sdružení Antikomplex vydalo nakladatelství Českého lesa, Domažlice.

Mikšíček P., Spurný M., Matějka O., Spurná S. 2007, Zmizelé Sudety, Pro občanské sdružení Antikomplex vydalo nakladatelství Českého lesa, Domažlice.

Mikšíček P., Spurný M., Matějka O., Spurná S. 2015, Zmizelé Sudety, Antikomplex a kolektiv autorů, [Praha].

Mirtes H. 1992, Verfall einer Kulturlandschaft am Beispiel des Alt-Landkreises Mies im Egerland, Heimatkreis Mies-Pilsen, Dinkelsbühl.

Mommsen H. 2001, Der „Ostraum“ in Ideologie und Politik des Nationalsozialismus, [w:] Mühle E. (ed.), Mentalitäten - Nationen - Spannungsfelder: Studien zum Mittel-und Osteuropa im 19. und 20. Jahrhundert, Herder Institut, Marburg, s. 163-172.

Nijakowski L. M. 2006, Domeny symboliczne, Konflikty narodowe i etniczne w wymiarze symbolicznym, Publisher, Scholar, Warszawa.

Norberg-Schulz Ch. 2010, Genius loci. Krajina, misto, architektura, Dokořán, Praha.

Nosková H. 1991, Čeští a slovenští novoosídlenci na Sokolovsku a mistni nèmecké obyvatelstvo po roce 1945, „Český lid“, Vol. 78, No. 2, s. 106-116.

Pešková J. 1998, Role vědomí v dějinách, Nakladatelství Lidové noviny, Praha. 
Plicka I. 2008,Jak (ne-)umime žit v naši sudetské krajině - kdysi a dnes, [w:] Říha M. (ed.), Promèny sudetské krajiny jako poselstvi dalším generacím, Společnost pro trvale udržitelný rozvoj, Praha, s. 8-9.

Putna M. C. 2001, Šumavská literatura: řeky, cesty, modely, [w:] Svatoň V., Housková A., Kultura a misto, Studie z komparatistiky III, Mlejnek, Pardubice, 51-95.

Sádlo J., Pokorný P., Hájek P., Dreslerová D., Cílek V. 2008, Krajina a revoluce, Významné přelomy ve výroji kulturni krajiny českých zemi, Malá Skála, Praha.

Samojský P. 2011, Krajina jako duchovni dédictví, Úvodní rozblédnutí, Obec širšího společenství českých unitářů, Praha.

Seibt F. 1996, Némecko a Češi, Dëjiny jednoho sousedství uprostřed Evropy, Academia, Praha.

Schama S. 1995, Landscape and Memory, Knopf, New York.

Schama S. 2007, Krajina a pamèt', Argo, Dokořán, Praha.

Scholz M. 2012, Prostor a dëjiny: Historické promèny diskusí a otázky současnébo bádání, [w:] Klusáková, L., Scholz M. (ed.), Pojetí prostoru v historické perspektivee, Karolinum, Praha, s. $13-28$.

Sigmund H. 2006, Dìm ve Stecherově ulici, Vzpominky na dětstvi v Sudetech v letech 1938-1946 Hubert Sigmund, Prostor, Praha.

Srb V. 1988, Demografický profil némecké menšiny v Československu, „Český lid“, Vol. 75, No. 1, s. 29-42.

Soukupová B. 1994-1996, Pražská společnost střednich vrstev v letech 1930-1938, K perspektivám mezietnického soužití na území jednoho státu, [w:] Město a jeho kultura, Lidé města 6, Praha, s. 66-92.

Soukupová B. 2007a, Klub za starou Prabu, památky a pamèt. Reflexe starobylosti a krásy mèsta v české společnosti koncem 19. a ve 20. století, [w:] Soukupová B., Novotná H., Jurková Z., Stawarz A. (ed.), Město - identita - pamèt', Zing print, Bratislava, s. 14-32.

Soukupová B. 2007b, Vltava a Praha: partnerství a rivalita, Vltava jako symbol češství a českoslovenství, [w:] Stawarz A. (ed.), Miasto po obu brzegach rzeki - Różne oblicza kultury, Warszawa, s. $25-46$.

Soukupová B. 2008, Vlast a domov u autochtonnich národnostnich menšin v ěeských zemich (na prìiladu strukturované židovské, némecké a romské menšiny), [w:] Bittnerová D., Heřmanský M. (ed.), Kultura českého prostoru, prostor české kultury, Praha, s. 73-82.

Soukupová B. 2009, Juden und tschechische Deutsche in den böhmischen Ländern in der ,posteuropäischen "Zeit, [w:] Pilvousek J.,Preuss E. (ed.),Aufnahme-Integration-Beheimatung, Flüchtlinge, Vertriebene und "Ankunftsgesellschaft", Studien zur kirchlichen Zeitgeschichte, Berlin, s. 43-59.

Vařeka J.1985, Sídelní zmèny v novoosidleneckém pohraniči ČSR, „Českýlid“, Vol. 72, No. 2, s. 65-71. Vokolek V. 2000, Krajiny vzpominek, Triáda, Praha.

$V$ hodinè dvanácté, Soubor projevui státního presidenta a členů vlády Protektorátu Čechy a Morava po 27. kvètnu 1942, Orbis, Praha, srpen 1942. 
Wagnerová A. 1993, Odsunuté vzpominky, Z vyprávèni mých sudetonèmeckých generačnich vrstevnikui, Prostor, Praha.

Watzlik H. 1940, Sudetendeutsche Reden und Aufrede, Verein Böhmerwaldmuseum in Oberplan, Oberplan.

Zimmermann H. D. 2009, Tschechien, Beck, München. 